\title{
Enhancing Food Security through Acclimatized Species Domestication in the Haor Region
}

\author{
Md. Rahimullah Miah
}

Leading University, Sylhet, BANGLADESH

\begin{abstract}
Stratagem to promote improvement based on the cultivating, nurturing, harvesting, jamboree, processing, collecting period and diversifying of acclimatized species implicitly target households as principal beneficiaries in haor region of Bangladesh. This paper suggests that the cultivation and domestication of acclimatized species can play important roles for enhancing food security in these co-managed areas. Sunamgonj is a haor based district in Bangladesh where local communities are affected by the unwanted deluge throughout the approximately six months round the year. Most of haor inhabitants are hampered on food insecurity including fundamental needs and networks in this period. For these overcomes, succession of vegetative-floristic compositions including fauna and genetic diversification introduced in these areas not only for upliftment of food security but also shelter bank free from devastating. This study focuses on four Upazillas in Sunamgonj that derive a significant portion of their livelihoods from providing of cultivated species including flora and fauna in the mentioned haor region. The author applied social science methods for relevant data and information collection surrounding these haor areas. About $65 \%$ respondents of these regions are opined for seasonal species cultivation and domestication through the co-managed partners both government and development organizations including national and international agencies. The author wants to aware for species selection, domestication, tending, training and development among the enthusiastic farmers on the priority requirements on species gene bank to accomplish a broader concept of food security and to ensure that short-term food benefits lead to longer-term food security. It concludes that both research on the cultivation and domestication of acclimatization and co-management practices that are needed to allow haor inhabitants to continue to live ensuring food security round the year in this region within a sustainable manner of haor resources. Finally, the author infers the future research trajectories of the co-managed approaches and recommendations for how to further sustainable develop the probable domesticated resources alternatively for food security in the aforesaid.
\end{abstract}

Key Words: Food Security, Acclimatization, Domestication, Comanagement and Haor

\section{INTRODUCTION}

Human evolution has followed a path of co-existence and co-evolution with other living beings. Nearly one billion people go to bed hungry every day (Mordechai etal, 2006). Planet earth is the one and only home for creatures to compete, co-exist and evolve; be it 
the microscopic algae or bacterium to the giant redwood tree or the blue whale. Human beings depend on plants and forests for their food, fuel, fodder, shelter, cloth, furniture, medicine and fund, and even for oxygen for breathing without which they can't imagine their existence on this earth surface. Thousands of years have gone back but still now we cannot think a single moment without plants from cradle to grave. Perhaps every components of our earth, either ancient or modern is the product of plants directly or indirectly. Plants are the basis for life on the earth and without plants there would be no life on our planet (Nishat, 1993). But these plants are diminished day by day from the earth indicating from haors, hills or forest lands by lack of public awareness and others interference factors. As a result, the world is facing in a great challenging movement of the conservation of plant diversity for food security for the present and upcoming generations. Although the challenge of sustainable management for biodiversity conservation, the interplay of environmental quality, economic vitality and social equity, lies in learning how to meet present human needs and improve quality of life without diminishing the earth's capacity to provide for the needs of present and future generations in the competitive technological arena. Plant species are important for life ensuring food security in the existing areas. In well planned locality, trees have been raised along roads and lanes and parks maintained for serving as a green belt and open space (Negi, 1998). But food security of vulnerable people could be seriously exaggerated by high cereal prices and agencies presage increasingly food insecurity in the long term. (FAO, 2010). The current increase in food prices could easily consequences in deteriorating food security for the most vulnerable due to difficult access to markets. WFP (World Food Programme) reports moderately high hunger while IFPRI (International Food Policy Research Institute) describes condition of alarming hunger (FAO, 2010).

Bangladesh, a very densely populated country lies in the north eastern part of south Asia between $20^{\circ} 34^{\prime} \mathrm{N}$ and $26^{\circ} 33^{\prime} \mathrm{N}$ latitude and $88^{\circ} 01^{\prime} \mathrm{E}$ and $92^{\circ} 52^{\prime} \mathrm{E}$ longitude. The country has a total land area of 14.3 million hectares of which 8.5 million hectares are net cropped area, 2.2 million hectares are under forests (excluding 0.27 million hectares village forest) and 0.73 million hectares are water ways [6]. Bangladesh is also one of the most populated countries in the world with a population of over 150 million living in an area of 147,570 square kilometers indicating 1,045 persons per square kilometre. About $80 \%$ of the population lives in rural areas and is mainly engaged in agriculture and related non-farm activities. More than two thirds of the rural population is landless or functionally landless, $44 \%$ are below the national poverty line and $29 \%$ are classified as very poor. Endowed with limited land and other natural resources, and with a high population density, poverty is the omnipresent problem in rural Bangladesh especially in haor regions. The country has the third highest number of poor people in the world. Haors of Bangladesh encompass an area of around $8000 \mathrm{~km}^{2}$ are home to about 20 million people. Geographically, the haor areas cover Sylhet, Moulvibazar, Hobigonj, B. Baria, Netrokona, and Kishorgonj districts. Bangladesh is the largest part disaster prone of the least developed countries. The Haor basin in the north-east of the country is predominantly vulnerable, because of its poor drainage and vulnerability to flash inundation which is a lowlying land that possesses enormous area of wetlands including haors, baors, beels, water storage reservoirs, fish Ponds, Rivers, streams, freshwater lakes and marshes, flooded cultivated fields and estuarine systems with extensive mangrove swamps. The existing haors, baors, beels and jheels are of fluvial derivation and are commonly recognized as freshwater wetlands. These freshwater wetlands reside in four landscape units - floodplains, freshwater marshes, lakes and swamp forests. Bangladesh is predictable to hold seven to eight million hectares of wetlands in the form of permanent rivers and streams (480,000 hectares), estuarine 
and mangrove swamps (610,000 hectares), shallow lakes and marshes (120 000-290 000 ha), large reservoirs (90,000 ha), small ponds and tanks (150 000-180 $000 \mathrm{ha})$, shrimp ponds (90000$115000 \mathrm{ha})$ and seasonally flooded flood plains (5,770,000 hectares) (Negi, 1993). Out of 2.2 million hectares of forest land only 0.93 million hectares are under tree cover which is about $40 \%$ of the Government management forest and remaining $60 \%$ includes the denuded grass land and scrubbed encroached lands (Baten, 1991). In Bangladesh, the annual growth rate of population was $1 \%$ where the proportion of undernourished population was $27 \%$ as well as rural population $72 \%$ (2008). On the other hands, the substantial circumstances of the haors and its poor communications infrastructure are the root causes of the high levels of poverty in the area. The extended period of flooding means only a single crop can be developed, controls settlement to restricted "islands" above deluge level, and has hindered the expansion of roads. 22Underprivileged communications deter access to schools and markets and limit occasion to increase production. Most of cultivated crops are damaged. Lack of roads has also discouraged the spread of the electricity supply grid. Lack of markets and power supplies has inadequate the growth of the non-farm sector. Low productivity in agriculture and lack of other employment opportunities drives. Low levels of instructive attainment mean that they can only get the lowest paid and least secure jobs (HILIP, 2011).

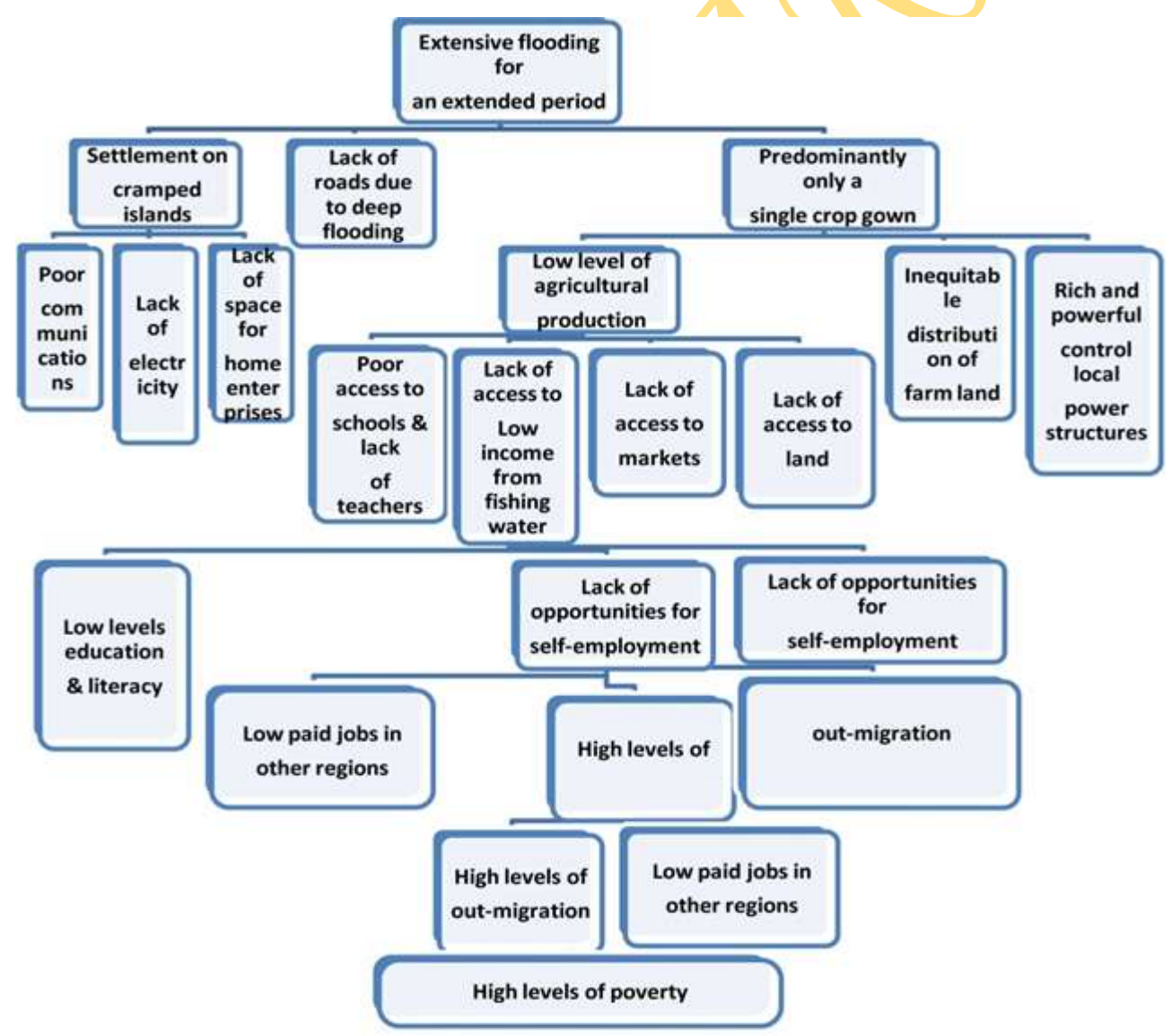

Figure 1: Drivers of Poverty in the Haor Region [22]

The Haor basin is a pocket of constant poverty. More than $28 \%$ of the total haor population 
lives below the lower poverty line (FSHB, 2012). The haor upazilas of the district of Sunamgonj are ranked among the poverty (hot-spots' of Bangladesh The World Food Programme (WFP) classify the haor region on food security atlas of Bangladesh as one of the "highly food insecure areas of the country. There are also some drivers of poverty in the haors (Prance, 1997) which is shown in the figure 1. The challenges facing us in food and agriculture are enormous and require both a collective effort and long-term solutions. Agriculture is the principal livelihood of the farmers who practice mono-culture (FSHB, 2012). This single crop remains under the constant threat of partial to complete damage from the early onrush of unwanted flood. Being inundated for over half the year, there is only limited potential for agriculture in the dry season - but different crops are vulnerable to flash floods. The haor inhabitants face economic, social and technical constraints in the pursuing their occupation. They are relatively poor and often cannot meet their basic needs from existing management practices. If the acclimatized species are introduced in the haor region with domesticated parameters including seasonal options for floating garden and relevant once, can be ensured optimum food security in the existing areas as well as conservation all types of biodiversity interlinked the haor master plan 2012.

\section{RATIONALE OF THE STUDY}

The rationale of this study, therefore, was to be observed the food security through acclimatized species domestication and its related processes namely: (i) Ensure Food Security in the haor region in Sunamgonj through adaptable species domestication, (ii) Introduce new model of Plant domestication like floating garden, home garden, (iii) Introduce comanagement system in haor region. In addition, there are some objectives of the study, viz. (a) To identify the developing and applying approaches, methods, tools and indicators for evaluating and measuring acclimatized species in haor region, (b) To establish linkages with information users, carriers and providers among government academia, business, development organization and others with global phenomena. Besides, the food security ensures that all inhabitants in Haor region throughout their life cycle enjoy at all times safe food in sufficient quantity and quality to satisfy their nutritional needs for optimal health. However, scientific and technological innovation will play crucial role in promoting global food safety and security and international cooperation will be vital.

\section{General Context of the Study}

\section{Food Security}

According to FAO (1996) Food Security exists when all people, at all times, have physical and economic access to sufficient, safe and nutritious food that meets their dietary needs and food preferences for an active and healthy life (FAO, 1996). Food Security is a high priority for Bangladesh which faces an extremely challenging food security dynamic (FSHB, 2012). Practically all households have adequate access to sufficient food to maintain an active and healthy life, without depending on humanitarian assistance. This means that there is adequate food available; that households have adequate resources to obtain sufficient food; and that they are healthy enough to receive the nutritional value of the food which is shown in the following figure1. According to the article 25 (1) of Universal Declaration of Human Rights (UDHR): Everyone has the right to a standard of living adequate for the health and well-being of himself and of his family, including food, clothing, housing and medical care and necessary social services, and the right to security in the event of unemployment, 
sickness, disability, widowhood, old age or other lack of livelihood in circumstances beyond his control (GHI, 2012).

Bangladesh is a signatory country of UDHR. The constitution of Bangladesh has declared the provision of basic necessities in the article 15 for her citizens. Recently Bangladesh performs the improvement of food production and poverty reduction activities though little accessible shows the quality and quantity of food security for the large populations sustainably. According to the Global Hunger Index 2012, Bangladesh is the $68^{\text {th }}$ ranking among the 100 countries in the world [10] while her position is $81^{\text {st }}$ out of 105 countries on Global Food Security Index (GFSI) 2012 (GPSI, 2012). We can assume the status of food security in the haor basin in the country compared to GFSI.

\section{Food Access in our Forest Resources}

Food Access is ensured when all households and individuals within those households have sufficient resources to obtain appropriate foods for a nutritious diet. It is dependent on the level of household resources - capital, labour and knowledge - and on their prices.

\section{Nutritional value and Food Utilization}

Nutritional value and Food Utilization have to do with having adequate food of sufficient diversity to meet nutrient needs and utilization which is shown in the following Figure 2. A Conceptual Framework of Food Security in Bangladesh was shown in the Figure 2 with the miscellaneous determinants of food security condition in a common idea sharing. The framework highlights the hypothesized causal interaction between the diverse elements of food availability, access and utilization including sub-section-wise parameters.

\section{Acclimatized Environment and Plant Species}

Acclimatized environment implies the phenomena of Home garden, Roof garden, Floating garden, Natural and Artificial plantations. These ensure food, fodder, fuel wood, furniture, fund, water-belt, soil protection and fertilization and available rotation either short term or long term. Bangladesh is enriched with a lot of biodiversity including different types of acclimatized plants species which is adapted to existing environment with site quality and site factors. These acclimatized plant species tends to different categories, viz. home garden, roof garden, floating garden, natural and artificial plantations. These plantations imply food, fodder, fuel wood, furniture, fund, water-belt, soil protection and fertilization and available rotation either short term or long term.

\section{Plant Domestication}

There are a lot of plant diversified species in the haor region. These species are extinct, rare day by day from the haor basin. Every one harvest those through over-exploitation but no one plant tremendously. These are some wild, non-traditional and cultivated species in the haor region. Plant domestication is needed for these wild and non-traditional species to the acclimatized haor ecosystems. The domestication of plants is one of the first steps in poignant towards a full-fledged agricultural economy, although the process is by no means a one-directional movement. A plant is said to be domesticated when its native characteristics are altered such that it cannot grow and reproduce without human intervention. Domestication is thought to be the result of the development of a symbiotic relationship between the plants and humans, called co-evolution, because plants and human behaviors evolve to suit one another. In the simplest form of co-evolution, a human harvests a given plant selectively, based on the preferred characteristics, such as the largest fruits, and uses the seeds from the largest fruits to plant the next year (Mordechai etal, 2006). Plant domestication can be introduced according to acclimatized species availability in the Sunamgonj haor region through long-term afforestation program. 


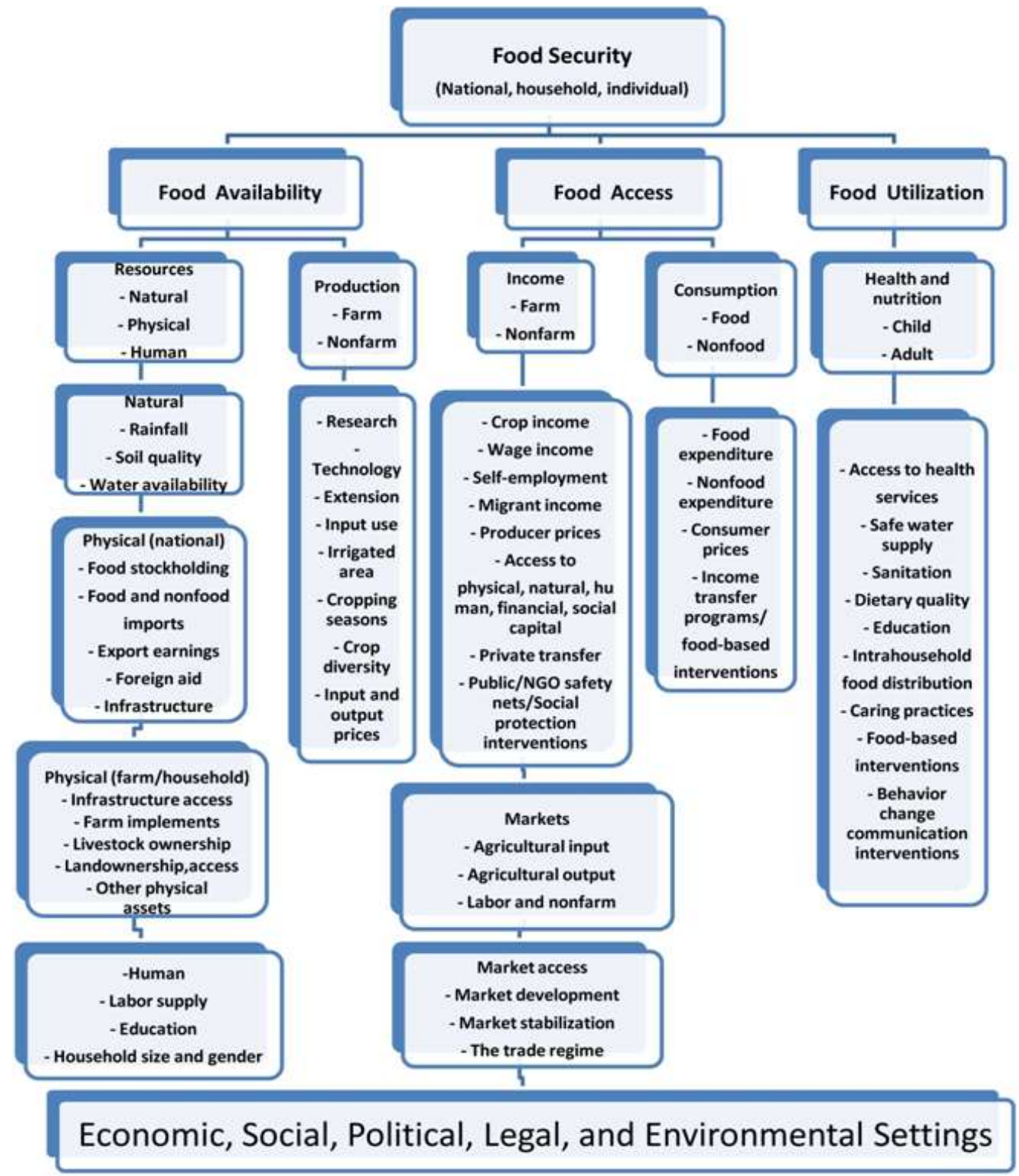

Figure 2: A Conceptual Framework of Food Security in Bangladesh [11]

\section{General View of Haor Region in Bangladesh}

Haors, which are bowl-shaped depressions between the natural levees of a river subject to monsoon flooding every year, are mostly found in the eastern region of the country, known collectively as haor basin covering an area of approximately $24,500 \mathrm{~km} 2$ (Chakraborty, 2006). There are altogether 411 haors comprising an area of about $8000 \mathrm{~km} 2$ dispersed in the districts of Sunamgonj, Sylhet, Moulvibazar, Hobigonj, Netrokona \& Kishoreganj. These Haors play an important role in the ecology, economy and livelihood of the country. Those wetlands have been highly explored for a long time; during the 
1990s the nation realized the needs of resource management seriously and from then the management and conservation of those water bodies got priority. Though the status of nations wetland management initiatives are not in satisfactory level but in some cases the success is appraisable and can be followed for management of different lake basins considering the socio-economic and ecological contest and with adaptation if necessary. There are 23, 590.08 hectares $(58,247$ acres) of gazette reed lands in the haors and low lying lands in the Sylhet Forest Division. These reed lands are bounded by $24^{\circ} 81^{\prime}-25^{0} 19^{\prime}$ north latitude and $91^{0} 39^{\prime}-92^{0} 23^{\prime}$ east longitude and are scattered distributed over 5 thanas in Companiganj, Dowarabazar, Chhatak, Gowainghat and Jaintapur in Sunamganj and Sylhet districts of the Sylhet Civil Division. The following table shows the traditional, nontraditional and wild plant species distributed in haor region.

\begin{tabular}{|l|l|l|l|}
\hline Sl.No. & Local Name & \multicolumn{1}{|c|}{ Scientific Name } & English Name \\
\hline 1 & Nal & Phragmites khakra & common reed \\
\hline 2 & Khagra & Saccharum spontanium & Kans grass \\
\hline 3 & Ekra & Eranthus ravannae & Eranthus \\
\hline 4 & Binna & Vetiveria zizaniodes & Eranthis \\
\hline 5 & Satamuli & Asparagus racemosus & Asparagus \\
\hline 6 & Hijol & Barringtonia acutangula & Barringtonia \\
\hline 7 & Baladumur & Ficus heterophylla & Fig \\
\hline 8 & Chitki & Phyllanthus disticha & Star Gooseberry \\
\hline 9 & Murta & Clinogyne diclotoma & Murta plants \\
\hline 10 & Bet & Calamus guruba & Bamboo Plant \\
\hline 11 & Other Plants & Agri-crops and forest crops & Gene-bank \\
\hline
\end{tabular}

Table 1: List of traditional, non-traditional and wild plant species in the haor region.

The reed lands in the freshwater marshes (marshes are more or less permanent shallow water bodies) are dominated by reed swamp associes, locally known as pujaban, and consist of tall grasses (about 6-7 meters tall) mainly Nal (Phragmites khakra), Khagra (Saccharum spontanium) and Ekra (Eranthus ravannae); some meadow grasses such as Binna (Vetiveria zizaniodes) etc; and woody shrubs like Satamuli (Asparagus racemosus) etc. Freshwater swamp forests develop in still water areas around lake margins and on the elevated ridges between the beels or levees of the streams and consist of evergreen trees (about 10-12 m height) such as Hijol (Barringtonia acutangula), Koroch (Pongamia pinnata), Bhuri (Trewia nudiflora), Jarul (Lagerstromia speciosa) etc; woody shrubs like Baladumur (Ficus heterophylla), Chitki (Phyllanthus disticha) etc; and asclepias climber, Murta (Sitalpati) (Clinogyne diclotoma), Bet (Calamus spp), Fishes, Shingles and Boulders etc; commercially important non-wood forest products, are also the natural resources of the reed lands. These (landscape units i.e., freshwater marshes and freshwater swamp forests do not necessarily occur in individual pattern; rather often occur in combinations). 


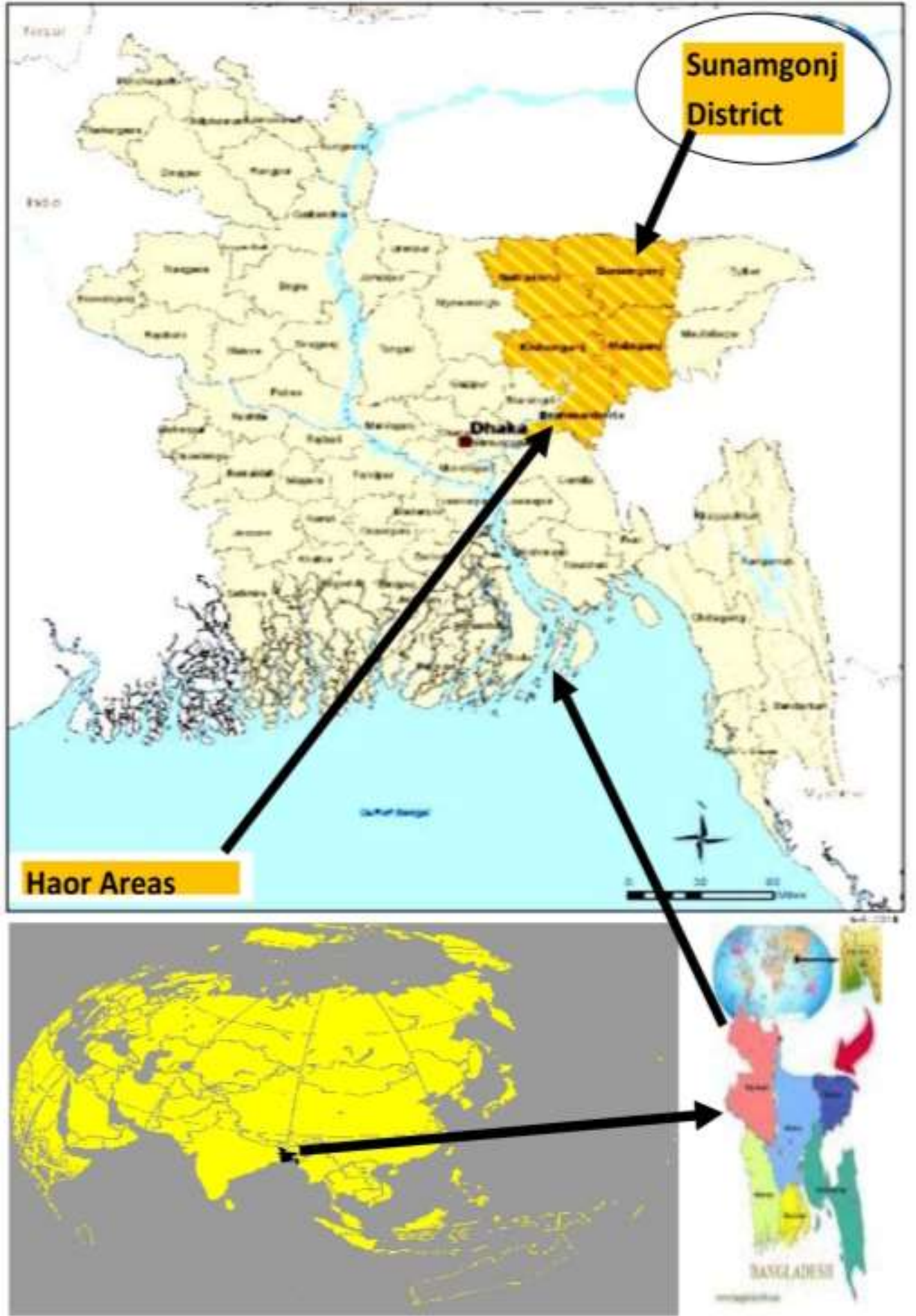

Figure 3: Haor Areas in Bangladesh 


\section{MATERIALS AND METHOdS}

The author visited in different places, body, institutions related to acclimatized species in the haor region for collecting primary and secondary data as usual. The fieldwork was conducted over a period of three months from August, 2011 -October, 2011. Most of the materials presented in this paper are based on literature review followed by field survey of the areas' biodiversity. While preparing this paper the mentioned steps were followed:

\section{Study Site}

Sunamgonj is a haor basin district constituted 95 haors in different upazillas which is located in the Sylhet Division with the Sylhet District to its east, Habiganj District to its south and Netrokona District to its west shown in the Figure 4. Sunamganj district city stands on the bank of river Surma and Located at $25^{\circ} 1^{\prime} 51^{\prime \prime} \mathrm{N}$ and $91^{\circ} 24^{\prime} 14^{\prime \prime} \mathrm{E}$ [24]. The Surma River and Kushiyara River run through the district. The River Dhawka also run through district sunamganj. The total population is 2443000 including area 3670 square kilometer and density of population is 666 per $\mathrm{km}^{2}$ (BBS, 2001). There are 11 upazilas in Sunamgonj, viz. Bishwamvarpur Upazila, Chhatak Upazila, Derai Upazila, Dharmapasha Upazila, Dowarabazar Upazila, Jagannathpur Upazila, Jamalganj Upazila, Sullah Upazila, Sunamganj Sadar Upazila, Tahirpur Upazila.

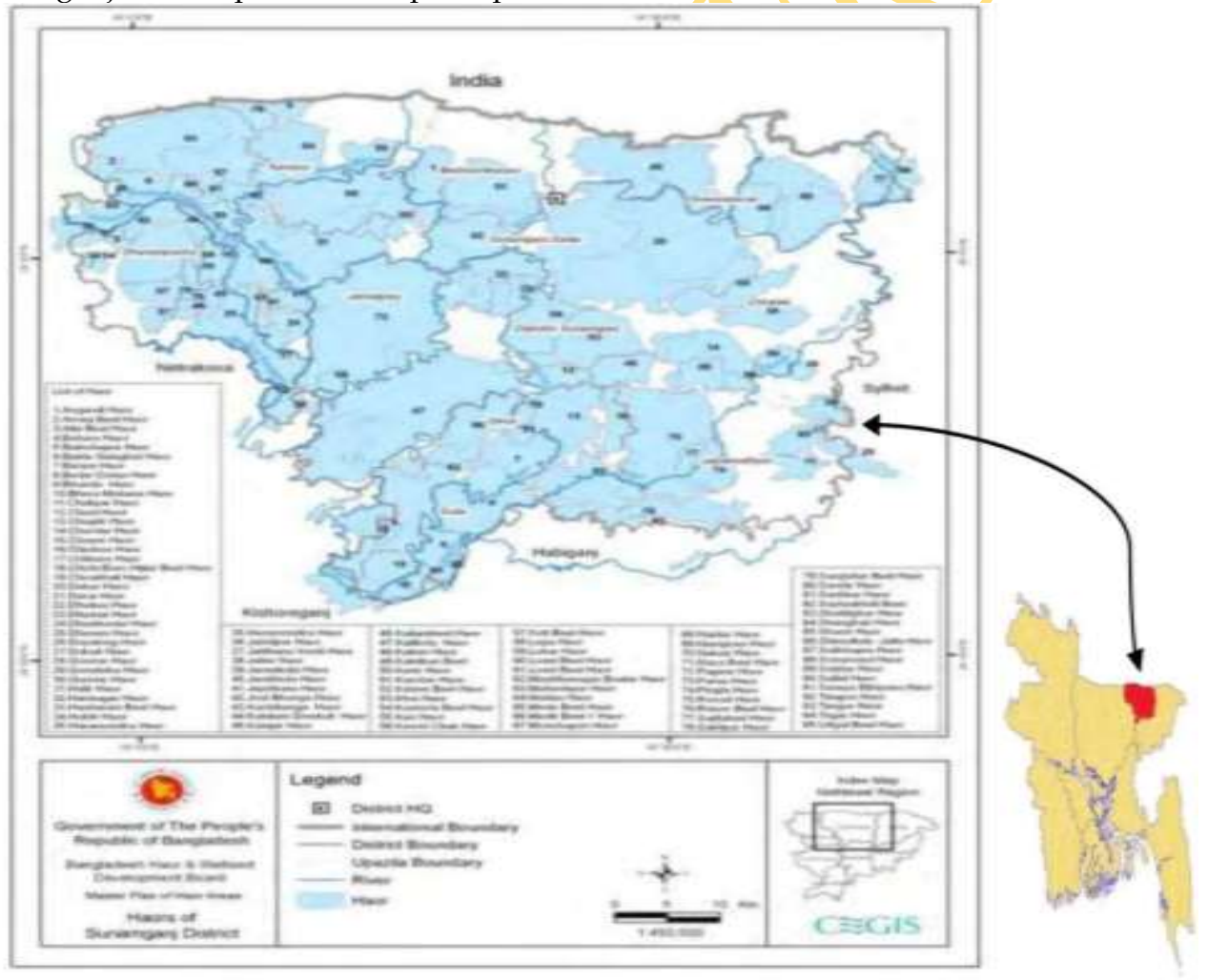

\section{Figure 4: Studied Haor Basin in Sunamgonj District of Bangladesh [13].}

\section{Reconnaissance Survey}

A phyto-sociological survey was prior to selection of sampling procedure to have an ideal of species composition in the four upozillas in Sunamgonj district viz. Sunamgonj Sadar, 
Jamalgonj, Bishwamvarpur and Tahirpur. After careful visual inspection of the species composition was found to differ from site to site, but homogeneity within the sites was observed. A suitable time activity schedule was followed to survey the relevant areas and to collect basic information like location, ownership, existing resource, site quality and relevant factors, vascular plants species composition, soil status, demographic profile, concerned authority and forest vegetation covers. The primary survey created a good basis for detail study.

\section{Data Collection}

Various methods were used during the data collection period. These included observations, interviews and questionnaires. Semi-structured interviews were used and interviewees were selected based on the representation point of view and additionally in regard to their relevance to the conceptual questions. Additionally, different interviews were taking from the key informants of relevant administrative, analyst, professional and local users of the existing phenomena. I surveyed households on the basis of their agrarian holdings (small, medium and large), and also interviewed representative groups of seniors, women, and youth. I collected socioeconomic information from each sampled household (member) regarding family size, age, sex, literacy level, and secondary occupations, land holdings, primary off-farm income, total annual earnings, and collection (amounts and timings) and availability of plant species.

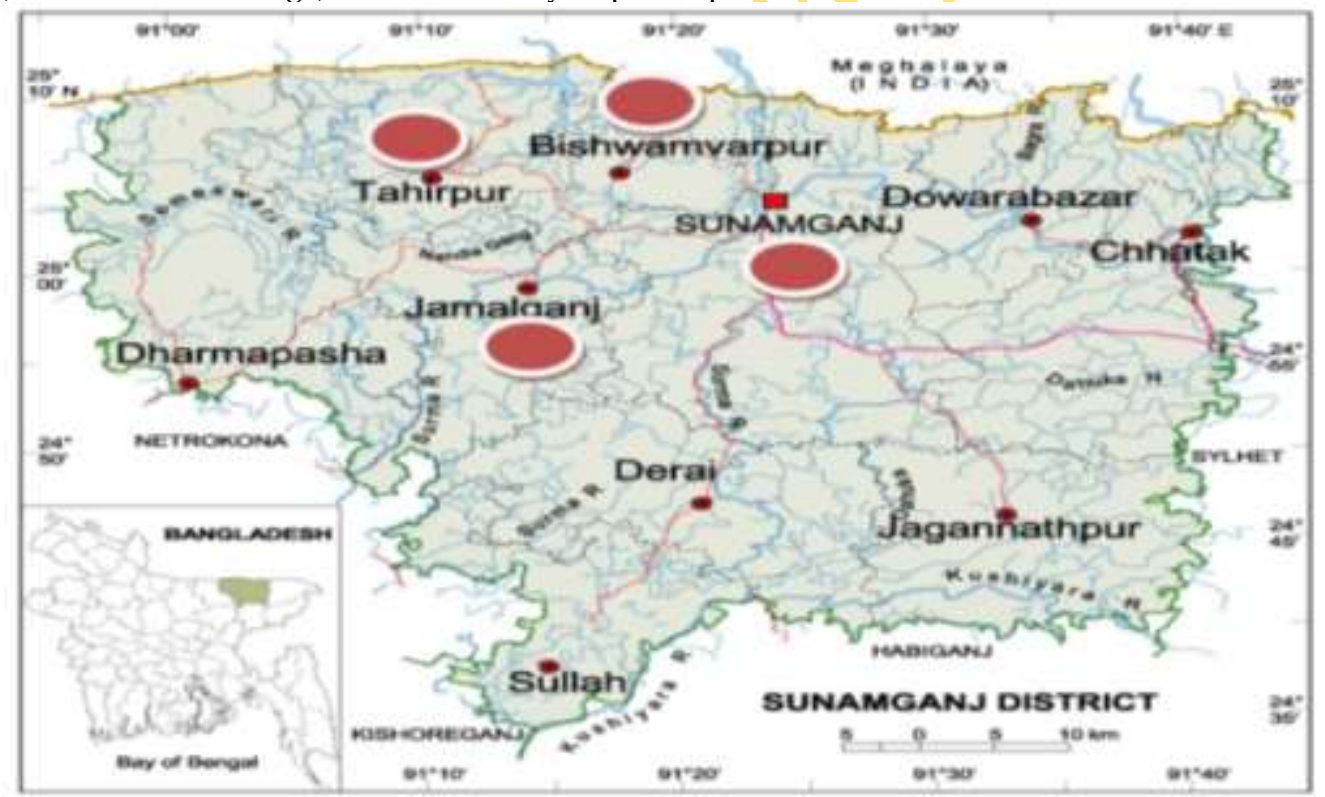

Figure 5: Studied Upazillas' at Haor Region in Sunamgonj District of Bangladesh

In addition, I conducted separate interviews with forest staff involved at the field level (forest guards and foresters), executive staff members (Range Forest Officers and Sub-Divisional Forest Officers), managerial officials (Assistant Conservator of Forest and Divisional Forest Officer at Sunamgonj beat office), and a local NGO Official. This was done in order to learn about institutional perceptions and problems at the administrative level. Upon completion of the research, I conducted a feedback meeting in order to share the research findings with the villagers and to obtain their suggestions and comments. Finally, vegetation surveys were carried out in 24 plots (two for each household) in order to determine the abundance of 
available species collected in the study area. Plots measured $20 \mathrm{~m}$ by $20 \mathrm{~m}$ each. In each plot, I noted the number of species, number of individuals, parts used, collecting season, uses and economic value for each species. Species selection was priority according to respondents demand, seasonal, perennial and helophytes.

\section{RESULTS AND DISCUSSION}

\section{Socioeconomic Data}

I surveyed all age groups, but the majority of respondents were in the lowest age classes, (2030) and (31-40) (Figure 6). They constitute the main work force in the upazilas. The maximum respondents (aged 31-40) at Sunamgonj Sadar are higher educated according to socioeconomic survey where the lowest respondents (aged >60) lived in other studied regions. The largest portion (33\%) of household heads interviewed were educated to the 10th grade level, $29 \%$ to the 5th grade, and $25 \%$ had secondary and higher secondary education, or HSC. Only $12.5 \%$ respondents had completed education above the HSC level.

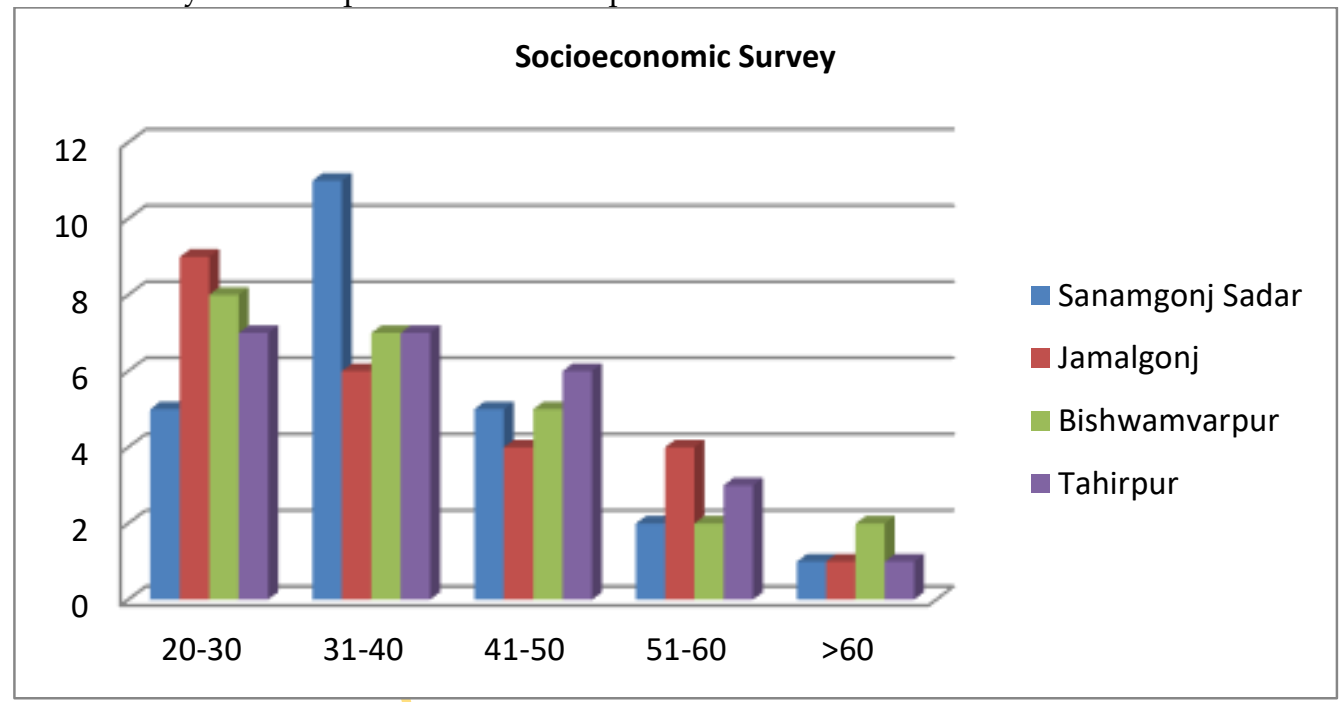

Figure 6: Socioeconomic survey in Sunamgonj Haor Region

They opined the establishment of helophytes on river embankments with a great variation of the water level demands a physical propagation and care and maintenance until the reed is recognized and dense enough to exclude tree plantlets through domesticated species.

\section{Respondent's reflection for species domestication}

Sunamgonj Sadar Upazilla

The Respondent's reflection for species domestication at Sunamgonj Sadar are varied according to the $55 \%$ respondents are strongly agree where $1 \%$ are disagree in a little bit accordingly in the figure 7 .

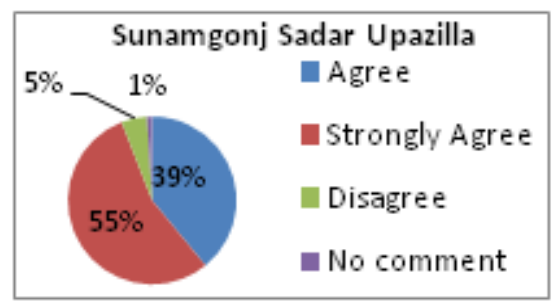

Figure 7: Respondent's reflection for species domestication at Sunamgonj Sadar 
Jamalgonj Upazilla

The Respondent's reflection for species domestication at Jamalgonj are varied according to the $65 \%$ respondents are strongly agree where $1 \%$ are disagree in a little bit accordingly in the figure 8 .

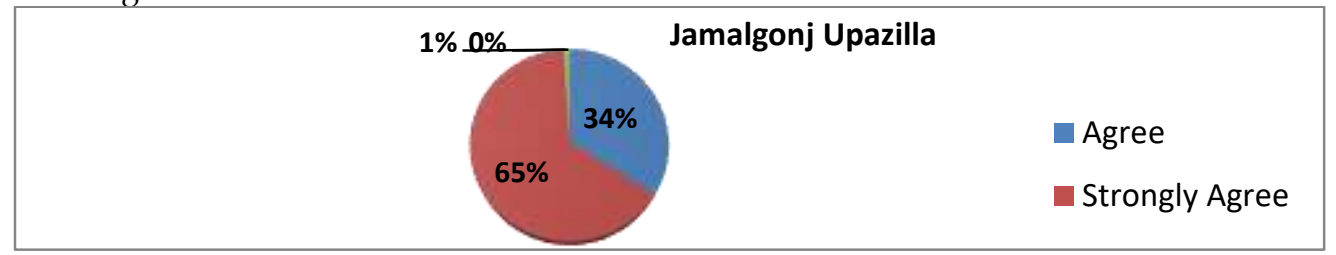

Figure 8: Respondent's reflection for species domestication at Jamalgonj

\section{Tahirpur Upazilla}

The Respondent's reflection for species domestication at Tahirpur are varied according to the $66 \%$ respondents are strongly agree where $1 \%$ are disagree in a little bit accordingly in the figure 9 .

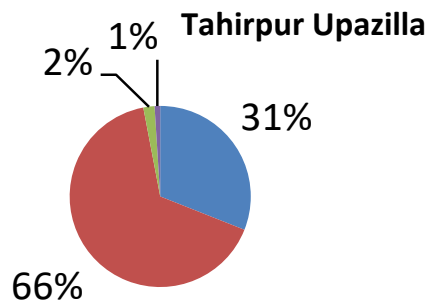

Agree

Strongly Agree

Disagree

No comment

Figure 9: Respondent's reflection for species domestication at Tahirpur

\section{Bishwamvarpur Upazilla}

The Respondent's reflection for species domestication at Bishwamvarpur are varied according to the $56 \%$ respondents are strongly agree where $2 \%$ are disagree in a little bit accordingly in the figure 10.

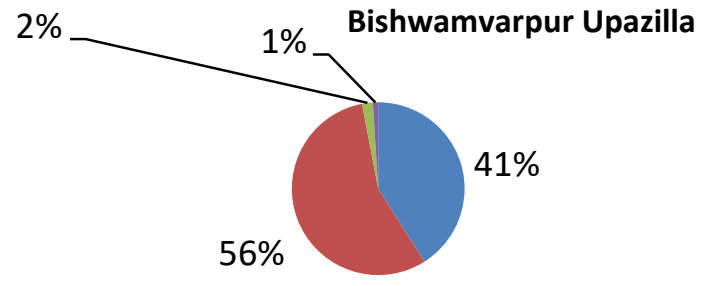

Agree

Strongly Agree

Disagree

No comment

Figure 10: Respondent's reflection for species domestication at Bishwamvarpur

\section{Acclimated Plant Species Domestication for food security}

Haor basin is covered by enriched biodiversity. The inhabitants of haor region depend on this biodiversity with different categories, viz. food, fodder, fuel wood, furniture, funds, function, fertilizer and others linked to social, cultural and economic values. These plant species are traditional, non-traditional or wild where are acclimatized in the existing environment. Day by day most of plant species are rare, extinct and endangered by man- 
made or natural calamities. Sometimes biodiversity hampered by unwanted deluge in haor region which is affected to the local people through providing food products within six months of the year. If acclimatized plant species can be domesticated in the existing areas with sustainable growth and development for the fulfillment of food security indicating food availability, food accessibility and food utilization as per the following species selection categories. Acclimatized species selection and domestication for food security in the haor region are listed as below:

- Flood Protection and Water-belt Species

- $\quad$ Floating Garden Species

- Home Garden Species

- Food Material Species

- Fodder Species

- $\quad$ Furniture \& Fuel Produce Species

- Fund Utilizing Species

- Pioneer and Climax Species

- Soil Protection Species

- Symbiotic multi-purpose Garden Species.

- $\quad$ Other gene-bank and mother tree species.

\section{Food SECURITY MotTo}

The framework of Food Security Motto Process consists of several steps which are mentioned in the following figure 11 indicating plant species selection and domestication on pioneer species, cereal species, climax species and acclimatized species with collectively required time for food collection and unwanted flood protection in the round year in the effective haor regions which is shown in the Figure 11. The implemented tasks can be monitored intensively by the effective authority for sustainable conservation and management.

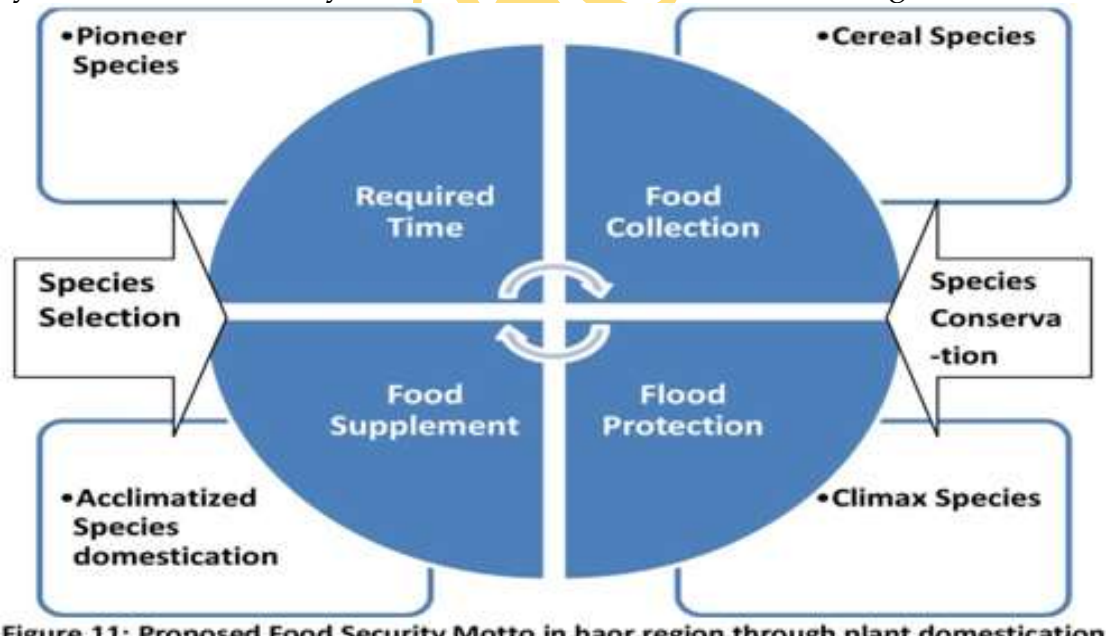

Figure 11: Proposed Food Security Motto in haor region through plant domestication

\section{Proposed Haor Food Security Database}

Integrated Haor Food Security Database model is the proposed model for the present and future generations at haor region for the purpose of relevant data sharing, updating, customizing and feedback meeting with technological arena which is shown in the 
following Figure 12. It indicated regional, sub-regional, divisional and national food security database involving community- based organizations.

\section{Integrated Haor Areas Management EnVisioning Food Security}

Overall, it has been formulated in an integrated manner haor areas management envisioning food security mainly flood management, expansion of education, settlement and health facilities, production of crops through seasonal species diversifications, road communication \& navigation, land zoning \& technology, water supply and sanitation, environmental sustainability, Afforestation, tourism, domestication of wild and nontraditional plants with species selection and acclimatization, use of mineral resources, generation of power \& energy, production of fisheries and livestock, women empowerment and haor technological arena with co-managed and stewardship phenomena which are shown in the Figure 12.

\section{Recommendations OF the Study}

The study recommends the implementation / establishment of a network of food security in critical areas like haors, and their management through acclimatized species domestication which are mentioned as below:

- Conduct a regional assessment of haor food security database with institution's relevant capacity.

- Create alternative food habit system among the existing haor inhabitants

- Proper utilization of Khas Land among the haor communities.

- Establish National and Regional focal point of reference in Haor Regions.

- Government Support with National Food Policy Plan of Action and Haor Master Plan

- Co-management Partnership among regional, national and global organizations and communities.

- Need Global Partnership Networks for capacity building.

- Future Research Trajectories through researchers and developers.

\section{CONCLUSION}

It brings to a close that both research on the crop growing and domestication of acclimatization and co-management practices that are needed to allow haor population to continue to live ensuring food security round the year in this region within a sustainable manner of haor resources. Training and capacity building can be introduced to the farmer for development of floating gardens, species domestication and relevant one. Finally, we focus potential research trajectories of the co-managed approaches and recommendations for how to further sustainable develop the probable domesticated resources including (i) Food Security and Nutrition Policy is comprehensive; clear objectives but inadequate instruments on Domestication, (ii) Food and nutrition security improved across livelihood mainly due to Plant Domestication, (iii) Lessons from Haor people offer an opportunity to improve on instruments, (iv) Some evidence illustrating that homestead food production makes a significant contribution to food security and incomes in season and out off season. 


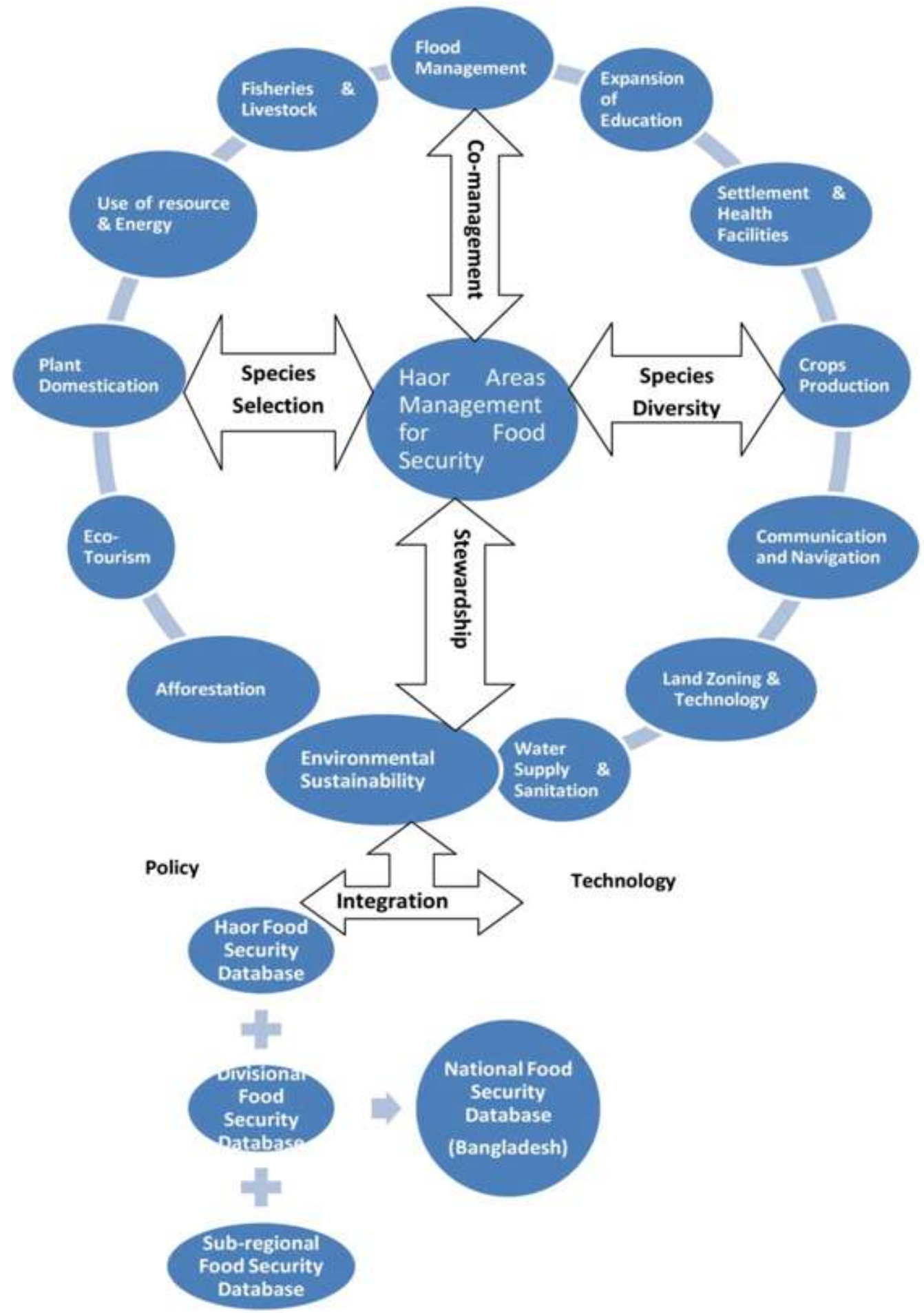

Figure 12: Integrated Haor Areas Management Envisioning Food Security 


\section{ACKNOWLEDGEMENT}

We are grateful to the Authority of the Department of Social Work of Shahjalal University of Science \& Technology (SUST), Institute of Development Affairs (IDEA), Campaign for Sustainable Rural Livelihoods (CSRL) and OXFAM-Bangladesh who were organized successfully the seminar on "Food Security in Haor Basin" in Sylhet, Bangladesh to progress this paper with indispensable and expert guidance, suggestions, constructive criticism, encouragement and inspiration throughout the paper presentation and feedback sharing to the food security seminar.

\section{REFERENCES}

Baten, S. A. 1991. Forestry situation in Bangladesh and problems related to forest conservation and protection. In: N. Q. Zabala, S. A. Baten and L. M. Rahman (eds.) Proceding of a training course on conservation and protection of Forest Heritage in Bangladesh. pp. 1-10.

BBS (Bangladesh Bureau Statistics). 2001. Bureau of Statistics of the Government of the People's Republic of Bangladesh. 2001. Population Census Preliminary Report (20012008).

BBS (Bangladesh Bureau Statistics). 2003. Overview: National-Series. Bangladesh Population Census, 2001. Ministry of Planning. Government of Peoples Republic of Bangladesh, Dhaka.

Chakraborty, T. R. 2006. Management of Haors, Baors, and Beels in Bangladesh: Lessons for Lake Basin Management. IUCN Bangladesh Country Office, Dhaka, Bangladesh, pp. 1-15.

FAO (Food and Agriculture Organization). World Food Summit, 1996.

FAO (Food and Agriculture Organization). 2010. Food Security Information for Decisionmaking. URL: www.foodsec.org

FMP (Forestry Master Plan). 1992a. Statistical report. Village Forestry Inventory, Forestry Master Plan. ADB TA 1355-BAN/UNDP/FAO/BGD/88/025.

FSHB (Food Security in Haor Basin).2012. Proceedings of the seminar on food security in Haor Basin, Shahjalal University of Science and Technology, October 15, 2012].

GFSI (Global Food $\quad$ Security Index).2012. http:/ / www.thedailystar.net/beta2/news/waste-not-want-not/

GHI (Global Hunger Index).2012.www.ifpri.org/ghi/2012/summary

HILIP (Haor Infrastructure and Livelihood Improvement Project). 2011. Drivers of Poverty in the Haors. Enabling Poor People to Adapt to Climate Change. Project Design Report-Main Report: Vol-I. P.56.

IFPRI (International Food Policy Research 2012. www.ifpri.org/ghi/2012/summary

IFPRI (International Food Policy Research Institute). 2013. The Status of Food Security in the Feed: The Future Zone and Other Region of Bangladesh. Bangladesh Policy Research and Strategy Support Program for Food Security and Agriculture Development, International Food Policy Research Institute, Dhaka, Bangladesh. p.22.]

Mordechai E. Kislev, Anat Hartmann, and Ofer Bar-Yosef. 2006. Early domesticated fig in the Jordan Valley. Science 312:1372-1374.

MPHA-Master Plan of Haor Areas. 2012. Bangladesh Haor and Wetland Development Board, Ministry of Water Resources, Government of the People's Republic of Bangladesh, Dhaka, Vol. II, pp.1-266. 
Negi, S.S. 1993. Biodiversity and its Conservation in India. Indus Publishing Company, New Delhi, India. Pp.26-43.

Nishat, A. 1993. Fresh water Wetlands in Bangladesh: Status and Issues. In: Nishat A, Hossain Z, Roy M K and Karim A (eds.) Freshwater Wetlands in Bangladesh-Issues and Approaches for Management. IUCN, 1993, pp 9-22.

PDR-Project Design Report.2011. Drivers of Poverty in the Haors. Haor Infrastructure and Livelihood Improvement Project, Enabling Poor People to Adapt to climate change, Bangladesh. p.56.

Prance, G.T. 1997. Plant diversity and conservation. In: Souvenir, $9^{\text {th }}$ Biennial Botanical Conference, 1996, Bangladesh Botanical Society,pp.29-38.

Quamrul, I.C. 2001. Bangladesh State of Biodiversity. Forum of Environmental Journalists of Bangladesh. Dhaka, Bangladesh. 5-15 pp.

Rashid, E.H. 1991. Geography of Bangladesh. University Press Ltd. 124-127 pp.

UDHR (Universal Declaration of Human Rights).

1948. http://www.un.org/en/documents/udhr/

Web 2 : http:/ / www.lged.gov.bd/ViewMap2.aspx?DistrictID=64

Web: www.multivu.com. 